\title{
Peritonitis Management through Appendicular Perforation in the Department of Surgery Bougouni Hospital (Mali)
}

\author{
Sidiki Keita1*, Koniba Keita², Mahamadou Coulibaly1, Moussa Sissoko', Lamine Soumare1, \\ Oumar Sacko1, Sekou Koumaré1, Adama K. Koita1, Soumaîla Keita1, M. Doumbia Dramane1, \\ Zimogo Zié Sanogo ${ }^{1}$
}

${ }^{1}$ General Surgery “A” Department, Hospital Point-G., Bamako, Mali

${ }^{2}$ General Surgery Department, Hospital BSS, Kati, Mali

Email: *sidikibafing@yahoo.fr

How to cite this paper: Keita, S., Keita, K., Coulibaly, M., Sissoko, M., Soumare, L., Sacko, O., Koumaré, S., Koita, A.K., Keita, S., Doumbia Dramane, M. and Sanogo, Z.Z. (2020) Peritonitis Management through Appendicular Perforation in the Department of Surgery Bougouni Hospital (Mali). Surgical Science, 11, 446-452.

https://doi.org/10.4236/ss.2020.1112046

Received: November 10, 2020

Accepted: December 15, 2020

Published: December 18, 2020

Copyright $\odot 2020$ by author(s) and Scientific Research Publishing Inc. This work is licensed under the Creative Commons Attribution International License (CC BY 4.0).

http://creativecommons.org/licenses/by/4.0/

\begin{abstract}
Introduction: Appendicular peritonitis is a complication of acute appendicitis characterized by the spread of the infectious process in the peritoneal cavity thus achieving wide spread or localized purulent peritonitis; it's a medico-surgical emergency. Our objectives are to determine the frequency, describe the clinical, therapeutic and prognostic aspects of peritonitis by appendicular perforations. Patients-Method: This was a 24-month retro, prospective, descriptive study from January 1, 2018 to December 31, 2019; conducted in the Bougouni Reference Health Center Surgery Unit. All patients of appendicular peritonitis at the Bougouni Reference Health Centre were included. Results: During the study period, 68 cases of generalized acute peritonitis including 30 appendicular peritonitis cases were collected. Appendicular peritonitis accounted for $44.1 \%$ of surgical procedures. Males accounted for $71.0 \%$ with a sex ratio of 1.2 at risk of men, the average age was 26.07 years. Abdominal pain and vomiting were the reasons for consultation in $86.7 \%$ and $76.7 \%$ of cases. Physical examination was used in most cases to make the diagnosis. X-ray of the abdomen without preparation, and abdominal ultrasound were performed systematically. Surgical treatment consisted of an appendectomy with peritoneal toilet followed by drainage. The average length of hospitalization was 8.8 days with extremes of 1 - 44 days. Hospital mortality was 3.3\%; morbidity and high mortality were related to delayed consultation. Conclusion: Appendicular generalized acute peritonitis is a medical-surgical emergency with a high mortality rate associated with delayed management.
\end{abstract}




\section{Keywords}

Appendicular, Peritonitis, Surgical Emergencies, Appendectomy

\section{Introduction}

Appendicular peritonitis is complications of acute appendicitis which is characterized by the spread of the infectious process into the peritoneal cavity, thus producing generalized or localized purulent peritonitis. It can appear immediately or follow the stage of appendicular abscess. Perforation is the rupture of the wall of the appendix putting its septic contents in communication with the peritoneal cavity. Peritonitis is a medical-surgical emergency and the prognosis can be serious.

Despite effective health coverage in the West, the incidence of appendicular peritonitis is not decreasing (20/100,000/year) [1]. Many studies carried out on peritonitis caused by digestive perforations have shown the predominance of appendicular perforations [2] [3] [4] [5] [6]. Flum. DR et al. [7] in the USA in a retrospective study of 63,707 appendectomies, found $25.85 \%$ of peritonitis by appendicular perforation. In Europe, Kraemer M. [8] in 2003 in a prospective multicenter study in 11 surgical departments in Germany and Austria on 519 cases of appendicitis, found $17.7 \%$ of peritonitis by appendicular perforation. In Africa, Chavda SK [9] in Kenya in 2005 in a retrospective and descriptive study on 289 patients operated on for appendicitis found $29.7 \%$ of cases of appendicular perforations with a morbidity of $19.4 \%$ and a mortality of zero. In Mali, numerous studies have shown the predominance of appendicular perforations in digestive perforations. SOGOBA G. [4] in a prospective study on non-traumatic digestive perforations obtained a frequency of $60 \%$ of appendicular perforations. DARRA MO [5] in a prospective and descriptive study, found 59 cases of acute generalized peritonitis, $84.3 \%$ of which were appendicular perforations.

In Bougouni, no study has so far been performed on appendicular peritonitis despite its high frequency. The lack of data on this pathology motivated us to do this work.

\section{Patients and Method}

\section{Type and study period:}

This was a 24-month retro prospective and descriptive retro study from January 1, 2018 to December 31, 2019.

\section{Study framework:}

The study took place in the general surgery unit of the Bougouni Reference Health Centre

\section{Study population:}

All of our patients were recruited from the general surgery unit of the Bougouni Reference Health Centre and operated on for appendicular peritonitis. A 
pre-established factsheet collected all the information for each patient.

\section{Inclusion criteria:}

All patients operated on for peritonitis whose origin was appendicular per operative.

\section{Non-inclusion criteria:}

Not included in the study were non-appendicular peritonitis, out-of-service surgery patients, and unusable records.

Data extraction: was done from texts and possibly tables and figures.

Parameters studied: The following parameters were analyzed: patient demographic characteristics (age, gender), clinical presentation, diagnostic confirmation, methods and therapeutic results.

Statistical method: The data collected was put together in a database in the form of an Excel $^{\circledR}$ table. Variables are expressed as mean or median with extremes. Data analysis was performed using Epi Info 7TM software.

\section{Results}

During the study period we performed 400 surgical procedures, 68 cases of acute peritonitis including 30 cases of appendicular peritonitis. The majority of our patients were between 15 and 30 years old, or $40 \%$. The average age was 26.07 years with extremes of 4 years and 70 years. Males accounted for $60 \%$ of cases with a sex ratio of 1.50 in favour of men. $90 \%$ of our patients came to the clinic 72 hours after the start of symptomatology, the average consultation time was 4 days. Abdominal pain was the most common reason for consultation with 26 cases or $86.7 \%$, it was accompanied by vomiting in 23 cases or $76.7 \%$; fever in 21 cases or $70 \%$; pulse acceleration of more than 100 pulses per minute in 22 patients or $73.3 \%$; hypotension in 17 patients or $56.7 \%$ and polypnea in 22 cases or 73.3\%. Pain was diffuse in 25 cases or $83.3 \%$; type of sting and burn in all patients; the onset was gradual in 17 cases or $56.7 \%$; its intensity was average in 15 cases or $50 \%$; 23 cases or $76.7 \%$; spontaneous in 17 cases or $56.7 \%$; it was calmed by painkillers in 17 cases or $56.7 \%$. The clinical examination had found the classic abdominal contracture in all patients. The abdominal ultrasound was performed in all our patients and had found a liquid effusion in 21 patients or $70 \%$. $\mathrm{X}$-ray of the abdomen without preparation was performed in 21 patients, or $70 \%$, and resulted in diffuse blurred greyness and hydro-aeric levels in all patients. All of our patients received preoperative care. It consisted of the installation of a nasogastric probe, a urinary probe, and electrolytic hydro-resuscitation. The type of anesthesia was a general anesthesia with orotracheal intubation. Xipho-pubal median laparotomy was performed in all of our patients. Surgical procedures performed were appendectomy, suction of suppuration and drainage of the peritoneal cavity by multi-perforated tubulated drains. The amount of intra-peritoneal effusion was less than $500 \mathrm{ml}$ in 26 cases or $86.7 \%$, the fluid was purulent in all patients. The appendix was punctured at its base in 5 cases or $16.7 \%$ and perforated at the top in 25 cases or $83.3 \%$. Immediate surgical fol- 
low-ups were simple in $93.3 \%$ of our patients or 28 cases. The morbidity rate was 1 case of parietal suppuration or $3.3 \%$. The mortality rate was $3.3 \%$, one case.

\section{Discussion}

We conducted a 24-month retrospective and descriptive study from January 1 , 2018 to December 31, 2019, including 30 patients operated on for appendicular peritonitis. The clearance was based on hospital records and operational reporting records. Difficulties in archiving files, the inadequacy of the technical platform made it impossible to carry out some additional examinations in an emergency, the low purchasing capability of patients made it difficult for some patients to take care of quickly. Despite advances in the management of appendicitis, the frequency of appendicular peritonitis remains high [5] [9] [10] [11]. Appendicular peritonitis accounted for $44.1 \%$ of acute peritonitis (68 cases) and $7.5 \%$ of all surgical procedures. Sex is not a risk factor for appendicular peritonitis, however the observed male predominance is consistent with the other series [6] [12] [13]. The average age of 26.07 is explained by the youth of the African population [13] [14] [15], on the other hand it is 39.8 years in France [13]. The average consultation time of 4 days is comparable to the African series [5] [12] [15], but lower than in Europe, which is 1 day [2] [13]. This delay in consultation is said to be related to the use of self-medication, traditional first-line treatment, lack of financial means and the absence of a health insurance system. Diffuse abdominal pain remains the dominant functional sign according to several authors [5] [6] [12] [15] [16]. Pain is accompanied by vomiting, stopping materials and gas [14] [17]. The rapidity of installation of general signs is correlated with the severity of peritoneal contamination [2]. Fever is usually high from the onset of the disease. Appendicular peritonitis produces an acute peritonitis picture that is essentially clinically diagnosed. Abdominal contracture is the major physical sign [18] [19]. If the examination is early it can be localized or limited to a simple generalized defense which is the semiological significance [15]. The stillness of the abdomen reflects the peritoneal attack, it is a symptom frequently encountered [2] [5] [20], it was found in 73.3\% of our patients. Pain in Douglas' cul-de-sac is of diagnostic interest in peritoneal syndrome and testifies to peritoneal irritation [2] [5]. Abdominal ultrasound has become a routine examination as long as the clinical diagnosis is not typical or to eliminate certain differential diagnoses [20]. Positive signs are a tubular structure more than $6 \mathrm{~mm}$ in diameter with sometimes an intra-luminal appendicolith not visible on the abdomen radiography without preparation. It is also possible to see an effusion in the peritoneal cavity perioperative (abscess) or diffuse (peritonitis) knowing that the absence of effusion does not eliminate peritonitis [20]. Undated abdomen $\mathrm{x}$-ray was requested in $30 \%$ of our patients because the diagnosis was already done with ultrasound. It allowed for the objective of a diffuse fuzzy greyness in 4 patients $(13.3 \%)$ and this greyness was associated with hydro-aeric levels in 2 patients or $6.7 \%$. Pneumoperitoneum was not found in our study, its absence in 
appendicular perforation appears as a very important distinguishing sign [2] [21]. We did not perform an abdominal scan because of its unavailability. The goal of the treatment of appendicular peritonitis is to eradicate the infectious focus, fight infection and ensure hydro-electrolytic balance. Resuscitation is the first essential time, it combines: the hydro-electrolytic rebalancing by the infusion of solutes through a central venous pathway that allows the repeated measurement of the central venous pressure; the nasogastric tube needed to suck up gastric stasis fluids and quantify water losses; urinary tube for monitoring hourly diuresis and kidney function. All of our patients received resuscitation, this resuscitation was brief in the preoperative period and continued in post-operative. Antibiotic therapy is intended to prevent the spread of the infectious process by combating bacteremia [2]. The products used must be active on aerobic and anaerobicgerms, most commonly encountered and have good intra-peritoneal penetration. The combination of aminosides, imidazoles and betalactamines corresponds to this pattern [2]. We used the combination of ciprofloxacin, gentamicin and metronidazole. This association was used by several authors [22] [23] and was in accordance with the recommendations of the French Society of Anesthesia and Resuscitation [24]. Surgical management of appendicular peritonitis accounts for the bulk of therapy. It should be as early as possible. In the face of an appendicular lesion, appendectomy is the rule. The first preferred route was median laparotomy [12] [13]. In France in the series of MARIAGE M. [13] $96.6 \%$ of patients were operated on laparoscopy. Appendectomy associated with an abundant peritoneal toilet with physiological salt serum, suction and systematic drainage of the parieto-colic gutters and Douglas cul de sac were performed in all of our patients.

The morbidity rate of $3.3 \%$ differs statistically from that of African authors [10] [17], because of our smaller sample size. This was a parietal suppuration in a patient. Mortality from appendicular peritonitis ranges from $1 \%$ to $17 \%$ in Africa [10] [13] [17] compared to $1.1 \%$ in France [13]. The European literature estimates this mortality to beless than $10 \%$ [2]. In our series we had one death or $3.3 \%$. The prognostic factors reported in the African series are essentially: the delay in consultation related to certain traditional practices, and the absence of a technical plateau [11] [12]. The causes of death reported in the African series are: septic shock, hypovolemia, digestive fistula and multivisceral failures [5] [12] [13].

\section{Conclusion}

Appendicular peritonitis is one of the most common etiological features. They are characterized by a delay in consultation. Diagnosis is mostly clinical and management is medical-surgical. Although they have a good prognosis; mortality and morbidity are not negligible in developing countries. Improved technical plateau, adequate health coverage and health education could reduce mortality and morbidity. 


\section{Consent}

Informed patient consent, from a file pre-established in this context has been obtained. All patients have been informed and have given their consent.

The informed consent: The informed consent form was submitted and explained to all patients. They accepted and signed the form.

\section{Conflicts of Interest}

The authors declare no conflicts of interest regarding the publication of this paper.

\section{References}

[1] Internat Mémoire, éditions Vernazobres-Gregor, 99 bd de l'hôpital-75013. Paris: Urgences chirurgicales, 2ème Edition: $n^{\circ} 275$; péritonite P 109 en 2005.

[2] Faniez, P.L., Koffi, E. and Panis, Y. (1992) Péritonites appendiculaires. Revprat (Paris), 42, 706-710.

[3] Ohmann, C., Franke, C., Kraemer, M. and Yang, Q. (2002) Neues Zur Epidemiologic der akutenappendicitis. Der Chirurg, 73, 769-776. https://doi.org/10.1007/s00104-002-0512-7

[4] Sogoba, G., Sangare, S., Traore, L.S., Togo, A., Traore, A., Diakite, I., et al. (2013) Perforation digestives non traumatiques: Étiologies et pronostic à l'Hôpital somme Dolo de Mopti.

[5] Diarra, M.O. (2018) Prise en charge des péritonites appendiculaires à l'hôpital de Sikasso. Thèse Med. FMOS-N${ }^{\circ} 18 M 71$.

[6] Konaté, E.B. (2014). Péritonites aigües généralisées: Aspects thérapeutiques et pronostiques au service de chirurgie générale de l'hôpital FousseyniDaou de Kayes. Thèse méd. FMOS

[7] Flum, D.R., et al. (2001) Has Is Diagnosis of Appendicitis Decreased Over Time? A Population-Based Analysis. JMA, 286, 1748-1753.

https://doi.org/10.1001/jama.286.14.1748

[8] Kraemer, M., Kraemer, K. and Leppert, R. (1999) Perforating Appendicitis: Is It a Separate Disease? Acute Abdominal Pain Study Group. European Journal of Sur gery, 165, 473-480.

[9] Chavda, S.K. and Hassan, S. (2005) Appendicitis at Kenyatta National Hospital, Nairobi. East African Medical Journal, 82, 526-530. https://doi.org/10.4314/eamj.v82i10.9351

[10] Kanté, L., Diakité, I., Togo, A., Dembélé, B.T., Traoré, A., Maiga, A., et al. (2013) Péritonites aiguës généralisées à l'hôpital Sominé DOLO de Mopti: Aspects épidémiologiques et thérapeutiques. Mali Médical, Tome XXVIII, No. 3, 20-23.

[11] Yaokreh, J.B., Coulibaly, O., Kouamé, D.B., Koffi, K.M., Tembely, S., Kouamé, Y.S.G., et al. (2015) Etude descriptive des péritonites chez l'enfant au CHU de Yopougon EDUCI 2015. Revue International des Sciences Médicales, 17, 173-177.

[12] Malle, O.A. (2015) Péritonites au CSREF de la commune I de Bamako: Aspects épidémiologiques, cliniques et thérapeutiques. Thèse méd, Bamako- $\mathrm{N}{ }^{\circ} 14$.

[13] Bakhou, A. (2012) Les péritonites appendiculaires chez l'enfant Expérience du service de chirurgie pédiatrique générale du CHU Marrakech. Thèse Méd. Marrakech, $\mathrm{N}^{\circ} 2$. 
[14] Mariage, M. (2016) Péritonite stercorale d'origine appendiculaire: Une forme rare et grave d'appendicite aiguë. Thèse méd. Amiens $2016 \mathrm{n}^{\circ} 174$.

[15] Harouna, Y.D., Abdou, I., Saidou, B. and Bazira, L. (2005) Les péritonites appendiculaires généralisées à propos de 70 cas à l'hôpital national de Niamey. Communication scientifique ACAF, Bamako.

[16] Camara, B. (2008) Péritonites par perforation appendiculaire dans le service de chirurgie générale et pédiatrique de l'hôpital Gabriel Touré. Thèse Méd-Bamako.

[17] Berthe, A., Postairea, M., Cheikhlardb, A., Zaharc, J.R. and Bourgeta, P. (2012) Antibiothérapie dans les péritonites appendiculaires de l'enfant: Le relais par voie orale est-il effectué? Archives de Pédiatrie, 19, 1303-1307. https://doi.org/10.1016/j.arcped.2012.09.015

[18] Ouangre, E., Zida, M., Bonkoungou, P.G., Sanou, A. and Traore, S. (2013) Les péritonites aigües généralisées en milieu rural au Burkina Faso: À propos de 221 cas. Rev. Cames Santé, 1, 75-79.

[19] Barbier, J. and Carretier, M. (1988) Péritonites aigues Encycl Med-Chir Urgences, 24048 B10, 2: p18.

[20] Mondor, H. (1979) Diagnostics Urgents: Abdomen. 9th Edition, Masson 1190, $24 \mathrm{~cm}$.

[21] Jhobta, R.S., Attri, A.K. and kaushik, R. (2006) Spectrum of Perforation Peritonitis in India-Review of 504 Consecutive Cases. World Journal of Emergency Surgery, 1, Article No. 26. https://doi.org/10.1186/1749-7922-1-26

[22] Maiga, B. (2015) Contribution à l'étude des appendicites: Aspect clinique, anatomopathologique, et étiologique au CSREF de la commune I. Thèse Méd. Bamako $\mathrm{N}^{\circ} 15 \mathrm{M} 59$.

[23] Rohr, S., Lang, H., Meyer, C. and Mechine, A. (1999) Appendicite aigue EMC (Paris) gastro-entérologie, 9, 066 A10-11p.

[24] Ouali, M. and Rahil, O. (2014) Antibiothérapie pour péritonites appendiculaires chez l'enfant. Devons nous changer nos habitudes? Annales françaises d anesthésie et de réanimation, 33, A393-A394. https://doi.org/10.1016/j.annfar.2014.07.672 